\title{
Happamien sulfaattimaiden luokittelu ja viljelyn vaihtoehdot
}

\author{
Markku Yli-Halla
}

Soveltavan kemian ja mikrobiologian laitos, Maaperä- ja ympäristötiede, PL 27 (Latokartanonkaari 11), 00014 Helsingin yliopisto, markku.yli-halla@helsinki.fi

\section{Tiivistelmä}

Euroopan laajimmat happamien sulfaattimaiden esiintymät ovat Suomessa, Pohjanmaan rannikolla. Ne ovat kuivatuksen ja kalkituksen jälkeen hyviä viljelysmaita. Niiden pohjamaassa on lisäksi runsaat kasveille käyttökelpoisen typen varat, joita syväjuuriset kasvit voinevat hyödyntää. Salaojitetun sulfaattimaan pohjamaassa oleva sulfidi hapettuu vähitellen rikkihapoksi, joka liuottaa metalleja maa-aineksesta. Sulfaattimailta tulevat valumavedet ovatkin johtaneet kalakantojen heikkenemiseen ja suoranaisiin kalakuolemiin varsinkin kuivien kesien jälkeen. Ongelmia alkoi laajemmin ilmetä 1970-luvulla, kun sulfaattimaiden salaojitus yleistyi. Sulfaattimailta tulevaa happamuusongelmaa pidetäänkin yhtenä vaikeimmin ratkaistavana vesiensuojeluongelmana maassamme.

Viljeltyjen sulfaattimaiden tarkkaa levinneisyyttä Suomessa ei tiedetä, koska kattavia maaperäkartoituksia niiden esiintymisestä ei ole tehty. Arviot vaihtelevat 50000 - 330000 ha:n välillä sen mukaan, millaiset maat luetaan sulfaattimaiksi. Nämä maat eivät ole yhtenäinen ryhmä, vaan suurinta kuormitusta tulee todennäköisesti sellaisilta hiljattain salaojitetuilta alueilta, joilla sulfidikerrokset ovat lähellä maan pintaa $(<1,5 \mathrm{~m})$. Usein tällaisia alueita ovat lähellä rannikkoa olevat pengerrysalueet. Sulfaattimaat tulisikin jakaa erilaisiin luokkiin sen perusteella, minkä suuruista kuormitusta niiltä oletetaan tulevan. Erityyppisillä sulfaattimailla tarvitaan erilaisia toimia niiden maatalouskäytön ja ympäristönsuojelun tavoitteiden yhteensovittamiseksi.

Kun pyritään sulfaattimailta tulevan happamuuskuormituksen hallintaan, keskeistä on sulfidien hapettumisen estäminen. Tähän tavoitteeseen päästään, kun sulfidit pystytään pitämään mahdollisimman suuren osan vuotta pohjaveden pinnan alapuolella. Säätösalaojitus, varsinkin yhdistettynä kalkkisuodinojitukseen, on vähentänyt kuivatusvesien happamuutta ja metallipitoisuuksia. Menetelmä näyttää toimivan, jos sulfidikerrokset ovat melko syvällä (2-3 m). Viljelykasvien runsas vedenkäyttö kesällä johtaa väistämättä pohjaveden pinnan merkittävään laskuun säätösalaojituksesta huolimatta. Sellaisilla mailla, joilla sulfidikerrokset ovat lähellä maan pintaa, ne jäävät kesällä kuivilleen säätösalaojitetulla pellollakin, jolloin sulfidi pääsee hapettumaan. Tällaisilla mailla happamuuden syntyä voitaneen ehkäistä kuivatusvesien kierrättämisellä ja suoranaisella veden pumppaamisella ojastoon. Korkeaa pohjaveden pintaa sietävien kasvien viljely sulfaattimailla on tutkimisen arvoista. Äärimmäisenä toimena, joka saattaa tulla kysymykseen kaikkein vaikeimmilla alueilla, on kuivatuksen huomattava vähentäminen tai kuivatuksesta luopuminen. Näillä äärimmäisillä toimilla on huomattava vaikutus maatalouden harjoittamiseen ja tuotannon kannattavuuteen. Ennen kuin maatalouden kannattavuuteen ja tuotantoedellytyksiin kohdistuvia toimia ruvetaan edellyttämään, on selvitettävä, kuinka suurta maatilojen määrää ja kuinka suurta osuutta niiden pinta-alasta erilaiset toimenpiteet kohdistuisivat ja arvioitava tällä perusteella toimenpiteiden taloudelliset vaikutukset ja niiden toteuttamisen realistisuus. Tukijärjestelmiä on kehitettävä uusia vaatimuksia vastaaviksi. Luontoarvokaupan ulottaminen sulfaattimaille ja maanvaihtona toteutettavat tilusjärjestelyt voimakkaimmilla happamilla sulfaattimailla ovat harkinnanarvoisia vaihtoehtoja mahdollisten sulfaattimaihin kohdistuvien käyttörajoitusten kompensoimiseksi. Vaikka kattavia kartoituksia ei toistaiseksi ole olemassa, erilaisiin toimiin happamuuden syntymisen ehkäisemiseksi voidaan jo nyt ryhtyä tiedossa olevilla sulfaattimaa-alueilla.

Asiasanat: happamat sulfaattimaat, maankuivatus, salaojitus, happamuus, vesiensuojelu, mineraalityppi 


\section{Johdanto}

Euroopan laajimmat happamien sulfaattimaiden esiintymät ovat Suomessa, Pohjanmaan rannikolla. Salaojitetun sulfaattimaan pohjamaassa oleva sulfidi hapettuu vähitellen rikkihapoksi, joka liuottaa metalleja maaaineksesta. Sulfaattimailta tulevat valumavedet ovatkin johtaneet kalakantojen heikkenemiseen ja suoranaisiin kalakuolemiin etenkin kuivien kesien jälkeen, esimerkiksi syksyllä 2006. Ongelmia alkoi laajemmin ilmetä 1960-luvun lopussa ja 1970-luvun alussa, kun sulfaattimaiden salaojitus yleistyi (Manninen 1972). Sulfaattimailta tulevaa happamuusongelmaa pidetäänkin yhtenä vaikeimmin ratkaistavana vesiensuojeluongelmana maassamme.

Suomessa happamia sulfaattimaita on usein käsitelty yhtenä kokonaisuutena, vaikka niiden joukossa on ominaisuuksiltaan monenlaisia maita. Korkeammalla meren pinnasta sijaitsevat ja kauan sitten kuivatuksen piiriin tulleet sulfaattimaat ovat usein hapettuneet syvältä, ja niissä ollut happamuus on suureksi osaksi huuhtoutunut pois. Sen sijaan lähempänä rannikkoa sijaitsevissa sulfaattimaissa hapettunut ja huuhtoutunut pintakerros on usein ohuempi, ja pelkistyneitä rikkiyhdisteitä on melko lähellä maan pintaa. Mitä lähempänä maan pintaa sulfidikerrokset ovat ja mitä suurempi on niiden sulfidipitoisuus, sitä enemmän niistä vapautuu happamuutta, joka haittaa maanviljelyä ja aiheuttaa ongelmia vesistöissä. Ainakin Sirppujoen valuma-alueen kartoituksessa (Palko ym. 1985) ja Life Lestijoki-hankkeessa (Weppling ym. 1999) tutkittujen alueiden sulfaattimaat jaettiinkin luokkiin sen perusteella, miten paljon happamuuskuormitusta niiltä oletettiin tulevan vesistöihin. Myös esimerkiksi amerikkalaisperäisessä Soil Taxonomy -luokitusjärjestelmissä happamat sulfaattimaat jaetaan eri ryhmiin sulfidikerrosten syvyyden, maaprofiilin minimi-pH:n ja rikkipitoisuuden perusteella. Eri luokkia edustavien maiden paikallistaminen mahdollistaa nykyistä tehokkaamman riskinarvioinnin ja näille maille suunnattujen toimenpiteiden tehokkaamman kohdentamisen.

Happamat sulfaattimaat ovat tehokkaasti kuivatettuina ja kalkittuina hyviä viljelysmaita. Jotta näiden maiden säilyminen maanviljelyskäytössä voidaan turvata, tarvitaan kuivatustoiminnan ja valumavesien käsittelyn kehittämistä siten, että näiltä mailta vesistöihin tulevan happamuus- ja metallikuormituksen määrä vähenee nykyisestä. Parhaillaan ollaankin MMM:n ja YM:n toimesta laatimassa vuoteen 2020 asti ulottuvaa strategiaa happamien sulfaattimaiden aiheuttamien ympäristöhaittojen vähentämiseksi. Happamille sulfaattimaille soveltuvien käytännön toimien kehittämiseksi ja demonstroimiseksi on Siikajoen ja Pyhäjoen alueella käynnistynyt "HaKu"-hanke (2009-2011); CATERMASS LIFE+ -hanke (2010-2012) puolestaan toimii Etelä- ja Keski-Pohjanmaalla. Molemmissa hankkeissa myös kartoitetaan happamien sulfaattimaiden esiintyminen.

Tässä katsauksessa esitetään tuloksia siitä, miten sulfidipitoisen kerroksen esiintymissyvyys vaikuttaa näiltä mailta tulevan salaojaveden laatuun. Lisäksi esitetään tuloksia sulfaattimaan mineraalityppivaroista, jotka voivat olla huomattavan suuret. Katsauksessa käsitellään myös niitä tomenpidevaihtoehtoja, jotka voivat tulla kysymykseen pyrittäessä vähentämään happamilta sulfaattimailta tulevaa vesistökuormitusta, ja tarkastellaan alustavasti näiden toimien vaikutusta maatalouden harjoittamiseen.

\section{Aineisto ja menetelmät}

Tämä katsaus pohjautuu aikaisemmin julkaistuihin koetuloksiin, vuodesta 2008 MMM:n ja YM:n toimeksiannosta toimineen selvityshankkeen (MMM 2009) raporttiin ja sulfaattimaiden luokittelun osalta CATERMASS LIFE+ -hankkeen kartoitusosion valmisteluvaiheessa käytyihin keskusteluihin, joihin ovat osallistuneet Geologian tutkimuskeskuksessa, Åbo Akademissa ja Helsingin yliopistossa toimivat asiantuntijat. Sulfaattimaille perustettujen koekenttien salaojavesiä on monitoroitu kolmella paikalla: Limingan Tupoksessa v. 1984-1987 (Palko 1988) ja Ilmajoen ja Mustasaaren koulutiloilla v. 1988-91 (Joukainen ja Yli-Halla 2003). Tupoksen koealue oli tehty aiemmin viljelemättömälle maalle vartavasten tätä koetta varten, mutta Ilmajoen ja Mustasaaren kentät olivat jo pitkään viljelyssä olleilla pelloilla. Kaikilla kentillä oli noin metrin syvyyteen tehty salaojitus. Tiedot sulfaattimaan mineraalityppivaroista pohjautuvat Lapualla sijaitsevasta maasta tehtyihin määrityksiin (Paasonen-Kivekäs ja Yli-Halla 2003). Nämä maaprofiilit tutkittiin 240 cm:n syvyyteen saakka.

\section{Tulokset ja tulosten tarkastelu}

Kolme happamalla sulfaattimaalla sijainnutta koekenttää poikkesivat ominaisuuksiltaan toisistaan huomatta-

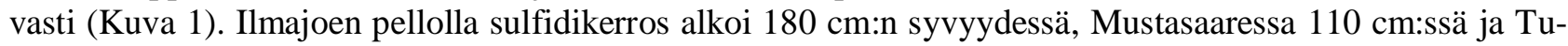
poksessa $60 \mathrm{~cm}: n$ syvyydessä. Tupoksen kentällä salaojat olivat siis sulfidikerroksessa, Mustasaaressa välittömästi sulfidikerroksen yläpuolella, mutta Ilmajoella sulfidia esiintyi vasta lähes metrin salaojien alapuolel- 
la. Sekä Ilmajoella että Mustasaaressa maan minimi-pH oli noin 3,7, mutta hiljattain viljelyyn otetulla Tupoksen maalla minimi-pH oli 3,4, jossa tämä pH oli myös lähimpänä maan pintaa $(50-60 \mathrm{~cm})$. Mustasaaressa la Ilmajoella minimi-pH oli syvemmällä $(100 \mathrm{~cm}$ ja $180 \mathrm{~cm})$, mikä heijastelee näiden maiden pidempää viljelyhistoriaa ja sitä, että hapettuva sulfidi oli syvemmällä.
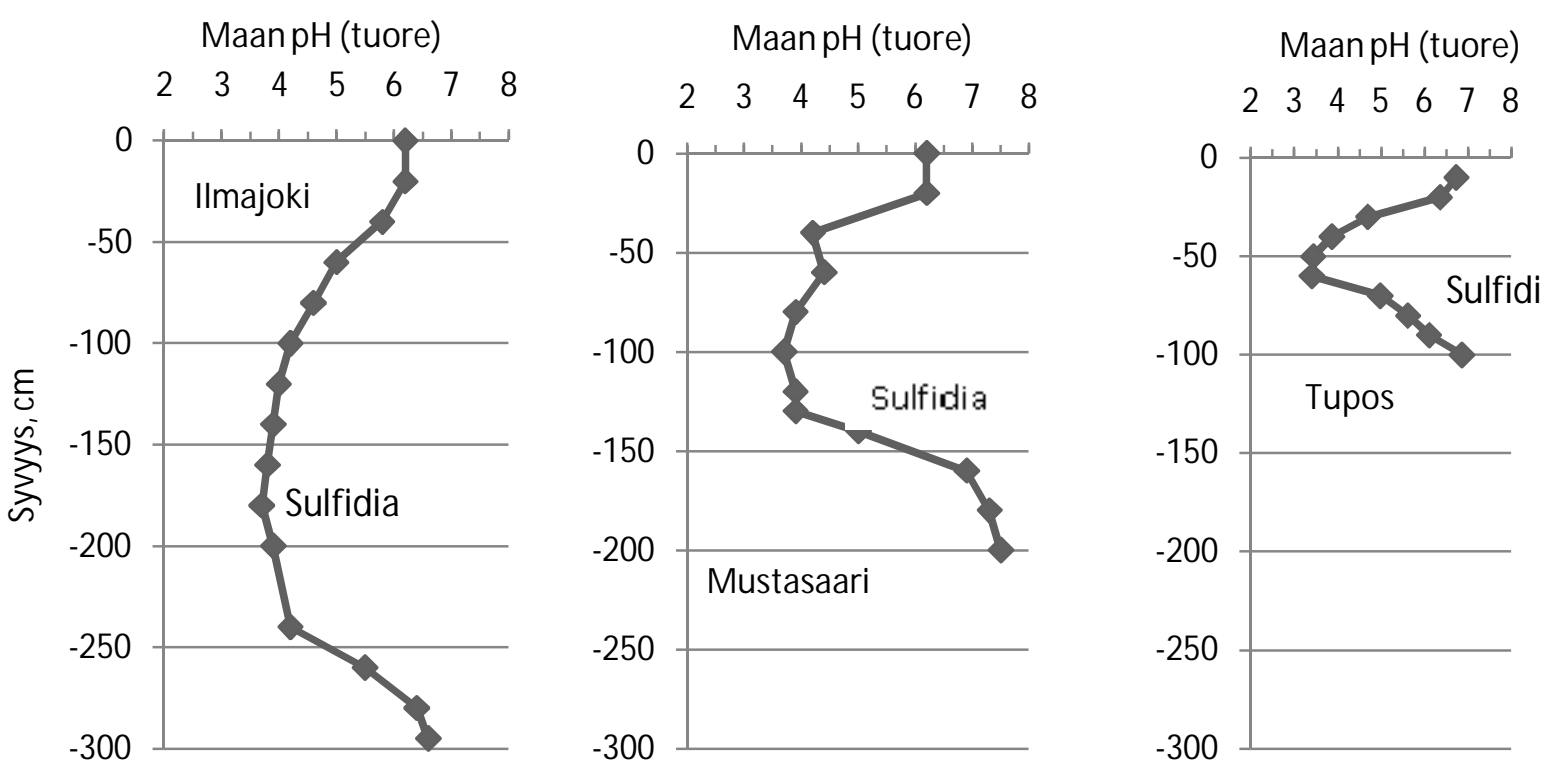

Kuva 1. Maan pH kolmella happamalla sulfaattimaalla. Ilmajoella sulfidipitoinen kerros alkoi 190 cm:n syvyydessä, Mustasaaressa $110 \mathrm{~cm}: n$ syvyydessä ja Tupoksessa $65 \mathrm{~cm}: n$ syvyydessä.

Nämä maan ominaisuudet näkyivät selvästi salaojavesien koostumuksessa (Taulukko 1). Tupoksen maalta tulvat vedet olivat selvästi happamimpia niin $\mathrm{pH}: n$ kuin asiditeetinkin perusteella. Myös Ilmajoen maan salaojavedet olivat selvästi happamampia kuin jokiveden raja-arvot, jotka ilmaisevat veden olevan eliöille haitallista.

Taulukko 1. Salaojaveden keskimääräinen asiditeetti ja pH kolmella koekentällä ja jokivededelle asetetut raja-arvot.

\begin{tabular}{|l|l|l|l|l|}
\hline Ominaisuus & $\begin{array}{l}\text { Tupos } \\
\text { Sulfidia } 65 \mathrm{~cm}: \mathrm{ss} \ddot{\text { ä }}\end{array}$ & $\begin{array}{l}\text { Mustasaari } \\
\text { Sulfidia } 110 \mathrm{~cm}: \mathrm{ssäa}\end{array}$ & $\begin{array}{l}\text { Ilmajoki } \\
\text { Sulfidia } 190 \mathrm{~cm}: \mathrm{ssä}\end{array}$ & Jokiveden raja-arvo \\
\hline Asiditeetti, mmol/1 & 18,0 & 11,5 & 3,4 & $<0,3$ \\
\hline $\mathrm{pH}$ & 3,5 & 3,8 & 4,3 & $>5,5$ \\
\hline
\end{tabular}

\section{Happamien sulfaattimaiden mineraalityppivarat}

Lapualla hienohietamaalla tehdyissä määrityksissä todettiin, että happamalla sulfaattimaalla oli syksyllä huomattavan suuret mineraalityppivarat $(430 \mathrm{~kg} / \mathrm{ha}, 0-240 \mathrm{~cm})$ verrattuna viereisellä lohkolla olevaan tavanomaiseen maahan (130 kg/ha). Molemmilla mailla oli viljelty pitkään perunaa, ja satojen ottamat typpimäärät olivat suuremmat kuin typpilanoituksen määrä. Sulfaattimaalla mineraalityppeä näytti kertyvän maan syvempiin kerroksiin nimenomaan ammoniumtyppenä $(310 \mathrm{~kg} / \mathrm{ha})$, kun taas tavanomaisella maalla ammoniumtypen pitoisuus oli pieni $(20 \mathrm{~kg} / \mathrm{ha})$. Molemmissa maissa oli suunnilleen saman verran nitraattityppeä (114 ja $124 \mathrm{~kg} / \mathrm{ha})$. Suuret ammoniumtypen varat sulfaattimaassa selittyvät sillä, että näiden maiden syvemmissä kerroksissa on runsaasti orgaanista ainesta, josta kuivatuksen seurauksena vähitellen mineraloituu typpeä. Mineraloituva typpi jää ammoniummuotoon eikä nitrifioidu nitraattitypeksi, koska näissä kerroksissa on liian vähän happea nitrifioivien bakteerien toiminnalle. Myös maan happamuus estää nitrifikaation. Ammoniumtyppi $\left(\mathrm{NH}_{4}^{+}\right)$sitoutuu maan kationinvaihtopaikkoihin eikä näin ollen huuhtoudu maasta. Ammoniumtyppi on kasveille käyttökelpoista. Voidaankin olettaa, että syväjuuriset kasvit voivat hyödyntää tätä maan luontaisista typpivaroista mineraloitunutta ravinnevarantoa. Käytännön viljelijät ovat tehneetkin tätä päätel- 
mää tukevia havaintoja. Sulfaattimaiden typpivaroja ja niiden vaikutusta typpilannoitustarpeeseen olisikin syytä tutkia.

\section{Happamien sulfaattimaiden luokittelukriteerit}

Luokiteltaessa happamia sulfaattimaita lähtökohtana on se, että voidaan erottaa ryhmiä ja rajata aloeita, joilla tarvitaan erilaisia toimia happamuus- ja metallikuormituksen torjumiseksi. Keskeistä on, että sulfidien esiintymissyvyys saadaan selville. Tällä perusteella voidaan arvioida, millaisia kuivatustoimia kyseisellä maalla voidaan turvallisesti tehdä. Lähtökohtana kartoitukselle ja luokittelulle on sulfaattimaita todennäköisesti sisältävien alueiden rajaus esimerkiksi maaperäkarttojen, korkeusdatan ja aikaisempien sulfaattimaakartoitusten antamien tietojen perusteella. Rajauksessa voidaan jossain määrin tukeutua myös alueelta tulevien valumavesien $\mathrm{pH}$-määritykseen, mutta varsinaisessa kartoitustyössä tutkitaan valittujen alueiden maaprofiileja tekemällä mittauksia ja aistinvaraisia havaintoja ja ottamalla maanäytteitä laboratoriossa tehtäviä analyysejä varten.

Maaprofiili joudutaan tutkimaan tarvittaessa jopa 2,5 metrin syvyyteen saakka. Silmävaraisesti tehdään havainnot maaprofiilissa eri syvyyksillä esiintyvistä maalajeista, pohjaveden korkeudesta ja siitä, millä syvyydellä mustaa rautasulfidia $(\mathrm{FeS})$ on mahdollisesti nähtävissä. Yksin musta väri ei kuitenkaan aina paljasta sulfidien olemassaoloa, sillä pyriittimuotoinen $\left(\mathrm{FeS}_{2}\right)$ on väriltään harmaata. Tuoreesta maasta, tehdään pH-määrityksiä eri syvyyksiltä (esim. $20 \mathrm{~cm}$ välein). Maanäytteiden annetaan hapettua 16 viikon ajan, minkä jälkeen niiden $\mathrm{pH}$ mitataan uudestaan. Maan pH:n aleneminen on kenttätutkimusten ohella kaikkein tärkein määritys, koska se osoittaa sen, onko näytteen edustamassa maakerroksessa maassa sulfideja. Jos maan $p H$ laskee hapettumisen aikana 4,5-4,0:n (raja-arvo vielä avoin) alapuolelle ja pH:n lasku on vähintään 0,5 pHyksikköä, maassa katsotaan olevan sulfidia. Näiden tietojen perusteella sulfaattimaat voidaan niiden maataloudelle ja ympäristölle aiheuttamien ongelmien perusteella luokkiin (Taulukko 2). Kukin luokka voidaan jakaa vielä alaryhmiin esimerkiksi sulfidikerrosten rikkipitoisuuden perusteella. Alustavia luokittelukriteerejä on kuitenkin vielä testattava maastokartoituksissa kertyvän aineiston avulla. Eloperäisillä mailla noudatettavat raja-arvot ovat vielä pohdittavina, koska humushapotkin voivat aiheuttaa melko matalia pH-arvoja.

Taulukko 2. Alustava ehdotus sulfaattimaiden luokittelemiseksi Suomessa.

\begin{tabular}{|l|l|}
\hline Luokka & Ominaisuudet \\
\hline I: hyvin vakava & $0-1,5 \mathrm{~m}$ syvyydessä sulfidia ja/tai $\mathrm{pH}<3,5$ \\
\hline II: vakava & $0-2,5 \mathrm{~m}$ syvyydessä sulfidia ja/tai $\mathrm{pH}<4,0$ \\
\hline III: melko vakava & $0-2,5 \mathrm{~m}$ syvyydessä sulfidia ja/tai $\mathrm{pH}<4,5$ \\
\hline IV: ei riskikohde & Ei sulfidia $0-2,5 \mathrm{~m}: \mathrm{n}$ syvyydessä, $\mathrm{pH}>4,5$ \\
\hline
\end{tabular}

\section{Sulfaattimaiden happamuuden säätely ja maatalouden vaihtoehdot}

Maatalous on elinkeinotoimintaa, joka antaa välittömästi tai välillisesti toimeentulon huomattavalle osalle maaseutuväestöä. Viljelijällä on valta viljellä hyväksi katsomiaan kasveja ja toteuttaa viljelyn näkökulmasta tarpeelliset kuivatustoimet. Maatalouden harjoittamisen kustannukset nousevat, jos viljelymailla joudutaan tekemään erityisiä toimia sulfaattimaalta tulevan happamuus- ja metallikuormituksen vähentämiseksi. Jos maata ei voi viljellä tehokkaimmalla tiedossa olevalla teknologialla, viljelijän tulot alenevat. Näillä seikoilla on huomattava vaikutus maatalouden kannattavuuteen happamilla sulfaattimailla. Näiden maiden käyttöä koskevia säädöksiä ei voikaan perustaa pelkästään luonnontieteellisille argumenteille. Ohjeiden ja säädösten taloudelliset ja sosiaaliset vaikutukset on tunnettava ja otettava huomioon maankäyttöä koskevia säädöksiä ja toimenpiteitä koskevia tukijärjestelmiä laadittaessa.

Laajimman käytettävissä olevan KUTI-tutkimuksen otanta-aineiston (Puustinen ym. 1993, Yli-Halla ym. 1999) perusteella sulfaattimaiksi eri kriteerien mukaan luokiteltujen maiden joukossa on ominaisuuksiltaan varsin erilaisia maita. Valtaosassa viljelyssä olevia sulfaattimaita sulfidikerrokset ovat melko syvällä (yli $2 \mathrm{~m}$ ), sulfidia on saattanut olla vähän ja sulfidin hapettumistuotteet ovat jo ehtineet huuhtoutua pitkään jatkuneen viljelyn aikana. Silti pohjamaassa on edelleen matala $\mathrm{pH}$. Tällaisilta mailta tuleva vesistökuormitus on todennäköisesti melko vähäistä, ellei kuivatussyvyyttä merkittävästi lisätä. Tällaisilla alueilla esimerkiksi säätösalaojitus mahdollisesti yhdistettynä kalkkisuodinojitukseen voi olla riittävä maataloudellinen vesiensuojelutoimi sulfaattimailta peräisin olevan happamuuden torjunnassa. 
KUTI-tutkimuksen perusteella maassamme voidaan arvioida olevan noin 50000 ha sellaisia viljelykäytössä olevia happamia sulfaattimaita, joilla sulfidikerrokset ovat lähellä $(<1,5 \mathrm{~m})$ maan pintaa ja joilta sen vuoksi tulee runsasta happamuus- ja metallikuormitusta. Voimakkaimmat happamuuden torjuntatoimet kohdistuisivatkin juuri näille pelloille, jotka siis edustavat rajoitettua osaa sulfaattimaa-alueestamme. Happamimmat ja suurinta happamuuskuormitusta aiheuttavat pellot sijaitsevat ilmeisesti lähimpänä rannikkoa tai muuten sulfaattimaa-alueiden alavimmilla paikoilla. Pengerrysalueet ovat tyypillisiä happamimpia sulfaattimaa-alueita.

Suurinta vesistökuormitusta aiheuttavilla pelloilla joudutaan todennäköisesti turvautumaan melko kalliisiin toimenpiteisiin, jos niiltä tulevaa kuormitusta halutaan merkittävästi pienentää. Näilläkin mailla olisi pyrittävä sellaisiin ratkaisuihin, joissa viljely voisi jatkua samalla, kun sulfaattimailta tuleva happamuuskuormitus vähenisi. Jotta tähän päästäisiin, voi viljelijän olla välttämätöntä luopua täysin vapaasta tuotantosuunnan ja viljelykasvin valintamahdollisuudesta ja siirtyä sellaisten kasvien viljelyyn, jotka mahdollistavat korkean pohjaveden pinnan. Tämä edellyttää säätösalaojitusta ja täydennysveden johtamista ojastoon kesän kuivana aikana mahdollisesti pumppaamalla.

Voidaan olettaa, että monivuotisia nurmia pystyttäisiin viljelemään pienempää kuivavaraa käyttäen kuin esimerkiksi viljoja. Myös peruna kasvaa happamalla maalla hyvin, ja sen viljelyssä lienee Suomessa ensimmäiseksi sovellettu säätökastelua ja kuivatusvesien kierrätystä. Uutena mahdollisena pellon käyttömuotona voi olla energiakasvien kuten ruokohelven viljely. Ruokohelpi kasvaa hyvin esimerkiksi turpeennostosta vapautuneilla suopohjilla, mutta energiakasvien viljelykokeita ei ole tiettävästi tehty happamilla sulfaattimailla. Näin ollen ei tiedetä, miten kyseiset kasvit menestyvät tällaisilla mailla ja kestävätkö ne tällä tavalla vähennettyä maan kuivatusta. Tästä aihepiiristä täytyy saada aikaan riittävän laajamittaisia kokeita ennen kuin menettelyä voitaisiin ruveta suosittelemaan tai edellyttämään.

Ellei kuivatuksen voimakas säätely ja tähän sopivien viljelykasvien valinta johda toivottuun vesistökuormituksen vähenemiseen, kuivatuksen lopettaminen ja maiden ottaminen pois varsinaisesta maatalouskäytöstä on todennäköisesti tehokas ratkaisu. Tämä toimenpide poistaisi kyseiset pellot viljelystä, ja ne voisivat toimia lähinnä laidunniittyinä.

Viljelymaan käytön mahdollinen rajoittaminen (kuivatustapa, viljelykasvivalikoima) tai tiettyjen uusien toimien vaatiminen aiheuttaa viljelijälle merkittäviä kustannuksia ja huomattavia sosio-ekonomisia vaikutuksia alueilla, joilla esiintyy runsaasti näitä suurinta vesistökuormitusta tuottavia happamia sulfaattimaita. Tilakohtaisten vaikutusten suuruus riippuu siitä, kuinka suuri osuus tilan pelloista sijaitsee tällaisilla sulfaattimailla ja siitä, mikä tilan tämänhetkinen tuotantosuunta on. Tuotantosuunnan vaihtaminen voi merkitä epärealistisen suuria investointikustannuksia. Jos alueen tiloista huomattava osa on edellä kuvattujen voimakkaiden toimenpiteiden piirissä, voi tällä olla vaikutusta koko kyläyhteisön tai kunnan taloudelliseen ja sosiaaliseen elinvoimaisuuteen.

Voimakkaat sulfaattimailta tulevan vesistökuormituksen vähentämistoimet tulevat kalliiksi, mistä syystä niitä varten tarvitaan tukijärjestelmä. Kalliiden toimenpiteiden tarkoituksenmukainen (kustannustehokas) kohdentaminen edellyttää nykyistä paljon tarkempaa kartoitustietoa tällaisten suurinta kuormitusta aiheuttavien sulfaattimaiden sijainnista ja myös tässä luonnosteltujen toimenpiteiden todellisesta vaikuttavuudesta. Toistaiseksi ei myöskään tarkkaan tiedetä, mitä viljelykasveja happamimmilla sulfaattimailla viljellään. Jotta happamuuden torjunnan vaikutukset maatalouden harjoittamiseen voidaan totuudenmukaisesti arvioida, on sulfaattimaa-alueen maatalouden tuotantorakenne selvitettävä tilakohtaisesti. Tämän perusteella pystytään laatimaan skenaarioita happamimpien sulfaattimaiden aiheuttaman vesistökuormituksen vähentämisen taloudellisista ja sosiaalisista vaikutuksista.

Tukijärjestelmiä on kehitettävä sulfaattimaiden viljelyä sääteleviä uusia vaatimuksia vastaaviksi. Luontoarvokaupan ulottaminen sulfaattimaille ja maanvaihtona toteutettavat tilusjärjestelyt voimakkaimmilla happamilla sulfaattimailla ovat harkinnanarvoisia vaihtoehtoja mahdollisten sulfaattimaihin kohdistuvien käyttörajoitusten kompensoimiseksi.

\section{Johtopäätökset}

Happamilta sulfaattimailta tulevan vesistökuormituksen merkittävä vähentäminen merkitsee väistämättä uudenlaista toimenpidevalikoimaa, suuria kustannuksia ja todennäköisesti huomattavia paikallistason sosiaalisia vaikutuksia.

Vaikka kattavia kartoituksia ei toistaiseksi ole olemassa, erilaisiin toimiin happamuuden syntymisen ehkäisemiseksi voidaan jo nyt ryhtyä olemassa olevan keinovalikoiman pohjalta tiedossa olevilla sulfaattimaa-alueilla. 


\section{Kirjallisuus}

Joukainen S \& Yli-Halla M. 2003. Environmental impacts and acid loads from deep sulphidic layers of two welldrained acid sulphate soils in western Finland. Agriculture, Ecosystems and Environment 95 (2003) 297 - 309.

Manninen H. 1972. Maankuivatustoimenpiteiden vaikutus veden laatuun lähinnä Kyrönjoen vesistöalueella. Diplomityö. Vaasan vesipiiri. Vesihallitus. $133 \mathrm{~s}$.

Paasonen-Kivekäs M \& Yli-Halla M. 2005. A comparison of nitrogen and carbon reserves in acid sulphate and non acid sulphate soils in western Finland. Agricultural and Food Science Vol. 14 (2005): 57 - 69.

Palko J. 1988. Happamien sulfaattimaiden kuivatus ja kalkitus Limingan koekentällä 1984 - 1987. Vesi- ja ympäristöhallinnon julkaisuja 19. $84 \mathrm{~s}$.

Palko J. 1994. Acid sulphate soils and their agricultural and environmental problems in Finland. Väitöskirja. University of Oulu. $58 \mathrm{~s}$.

Palko J, Räsänen M \& Alasaarela E. 1985. Happamien sulfaattimaiden esiintyminen ja vaikutus veden laatuun Sirppujoen vesistöalueella. National Board of Waters. Report 260. $95 \mathrm{~s}$.

Purokoski P. 1959b. Rannikkoseudun rikkipitoisista maista. Referat: Über die schwefelhaltigen Böden an der Kuste Finnlands. Agrogeologisia julkaisuja 74. 27 p.

Weppling K, Innanen M \& Jokela S. 1999. Life Lestijoki - happamien sulfaattimaiden hoito. Life Lestijoki - managing acid sulphate soils. WWF Finland Report No 11. 63 s.

Yli-Halla M. 2003. Pitääkö kaikkein happamimmat sulfaattimaat poistaa viljelystä? Suo 54(4):143-148. Suoseura Finnish Peatland Society. Helsingfors. 6 s.

Yli-Halla M, Puustinen M \& Koskiaho J. 1999. Area of cultivated acid sulfate soils in Finland. Soil Use and Management 15: 62-67. 